九州大学学術情報リポジトリ

Kyushu University Institutional Repository

\title{
Heavy Metal Concentration and Identification of Microorganisms in Soil under Roadside Trees of Daejeon City, Korea
}

Park, Gwan-Soo

Chungnam National University, Korea

Kim, Dong-Hun

Korea National University of Education

Lim, Jae-Goo

Chungnam National University, Korea

Ohga, Shoj i

Department of Forest and Forest Products Sciences, Kyushu University

https://doi.org/10.5109/4709

出版情報：九州大学大学院農学研究院紀要. 51 (1)，pp.53-56，2006-02-01. Faculty of Agriculture， Kyushu University

バージョン :

権利関係 : 


\title{
Heavy Metal Concentration and Identification of Microorganisms in Soil under Roadside Trees of Daejeon City, Korea
}

\author{
Gwan-Soo PARK ${ }^{1}$, Dong-Hun KIM ${ }^{2}$, Jae-Goo LIM ${ }^{1}$ \\ and Shoji OHGA*
}

\author{
Laboratory of Forest Resources Management, Division of Forest Ecosphere Management, \\ Department of Forest and Forest Products Sciences, Kyushu University, \\ Fukuoka 811-2415, Japan \\ (Received October 28, 2005 and accepted November 16, 2005)
}

\begin{abstract}
Due to the rapid urbanization and scarcity of land, most of metropolitan city of Korea are subjected to many potential pollution sources, including vehicle exhaust and industrial emissions. Soil samples were collected under roadside trees, Platanus occidentalis. and Ginko biloba, to study the current conditions of heavy metal contamination and microorganism in Daejeon city, one of the metropolitan city in Korea. The total concentrations of heavy metals in the samples were determined. The results indicate that soils of roadside trees in Daejeon city have elevated concentrations of $\mathrm{Cd}, \mathrm{Cu}, \mathrm{Zn}$, and $\mathrm{Pb}$. Especially, high metal concentrations in soil were found in old urban commercial district and heavy traffic areas, indicating that the major contamination sources in these soils are traffic emissions. Rhizosphere bacteria in soil of roadside trees in Daejeon area were characterized in that strain richness was lower than other soil samples. Bacterial community members were characterized by DNA sequence analysis of $16 \mathrm{~S}$ rDNA gene fragments following colony's DNA isolation emerged from nutrient agar medium using dilution plate method after soil sampling, polymerase chain reaction amplification and sequencing. Phylogenic analyses revealed that $16 \mathrm{~S}$ rDNA sequences were classified $\beta$-Proteobacteria, Actinobacteria, Gram-positive bacteria group. Among three study sites, Daejeon station, Daedeok science town, and Daehwa industrial complex, Daehwa industrial complex's soil microbe's richness was lowest. The $16 \mathrm{~S}$ rDNA sequence and fragment database constitutes a reference to which DNA profiles of roadside tree soil's bacterial communities can be compared.
\end{abstract}

\section{INTRODUCTION}

Heavy metals may come from many different sources in urbanized areas, including vehicle emissions, industrial discharge and other activities (Harrison et al., 1981; Gibson and Farmer, 1986; Thornton, 1991; Li et al., 2001). However, the extensive use of automobile is one of the most important sources of heavy metal contamination in the roadside environment (Garcia and Millan, 1994). These elements can give critical effect to the ecosystems and human health if they are present at high concentration levels.

In Korea, there has been an increase in scientific and public concern that heavy traffic are likely to result in a critical risks for the ecosystem and human health. Most studies (You and Son, 2003; Park, 1992) dealt with problems of heavy metal content in top soils and air, and mainly in Seoul, the capital city of Korea. However, in order to give a better picture of the heavy metal contamination, heavy metal content in soil should be also determined in other metropolitan city.

With the population of over 1.5 million and area of $539.59 \mathrm{~km}^{2}$, Daejeon is one of the most densely populated areas in Korea. The rapid urbanization and increasing vehicle have put great pressure on the local environment. Due to the scarcity of land, most of roads

${ }^{1}$ Department of Forest Resources, Chungnam National University, Daejeon 305-764, Korea

${ }^{2}$ Department of Biology Education, Korea National University of Education

* Corresponding author (E-mail: ohgasfor@mbox.nc.kyushuu.ac.jp) in Daejeon city are narrow and busy, and close to buildings, where the roadside trees are subject to potential pollution from various sources.

Although soils carry out important functions in ecological metabolism, soil ecology increasingly is degrading to the reasons such as population expansion and industrial activities according to the area. Plant interact with bacteria and fungi, some rhizosphere bacteria adhere tightly to soil fungal hyphae, whereas others are directly associated with the root surfaces (Bianciotto et al., 2001). The study of microbial diversity in natural environments has advanced significantly after the introduction of SSU rDNA-based molecular techniques (Amann et al., 1995). Since the knowledge on the diversity of road tree's soil microbial aggregates in city is lagging, an attempt to isolate and identify rhizosphere soil samples through molecular methods was made.

In this work the heavy metal concentrations and microorganism small-subunit (SSU) 16S rDNA gene sequence of the soil adjacent to roads of varying traffic flow were determined. The effect of the traffic flow to heavy metal content and identification of microorganism in soil under roadside trees, Platanus occidentalis and Ginko biloba, was studied.

\section{MATERIALS AND METHODS}

This study was proceeded in 2004 at the Daejeon city, southern part of Seoul, Korea. The total number of roadside trees in Daejeon city was 107,980 and $32.7 \%$ of the total trees was Ginko biloba L. and $15.9 \%$ was Platanus occidentalis L.(EPA of Daejeon city, 2004).

Four study sites were selected for this study. The 
Table 1. Characteristics of the study species.

\begin{tabular}{|c|c|c|c|c|}
\hline Sampling Sites & Species & $\begin{array}{l}\text { Mean } \\
\text { D.B.H* } \\
\text { (cm) }\end{array}$ & $\begin{array}{l}\text { Mean } \\
\text { Height } \\
\text { (m) }\end{array}$ & $\begin{array}{c}\text { Ages } \\
(\mathrm{yr})\end{array}$ \\
\hline $\begin{array}{l}\text { Chungnam } \\
\text { National } \\
\text { University }\end{array}$ & $\begin{array}{l}\text { Platanus occidentalis } \\
\text { Ginkgo biloba }\end{array}$ & $\begin{array}{l}38 \\
24\end{array}$ & $\begin{array}{r}10 \\
9\end{array}$ & $\begin{array}{l}35 \\
25\end{array}$ \\
\hline $\begin{array}{l}\text { Daejeon } \\
\text { Station }\end{array}$ & $\begin{array}{l}\text { Platanus occidentalis. } \\
\text { Ginkgo biloba }\end{array}$ & $\begin{array}{l}42 \\
34\end{array}$ & $\begin{array}{r}10 \\
8\end{array}$ & $\begin{array}{l}55 \\
50\end{array}$ \\
\hline $\begin{array}{l}\text { Daedeok } \\
\text { Science } \\
\text { Town }\end{array}$ & $\begin{array}{l}\text { Platanus occidentalis } \\
\text { Ginkgo biloba }\end{array}$ & $\begin{array}{l}22 \\
18\end{array}$ & $\begin{array}{r}10 \\
8\end{array}$ & $\begin{array}{l}25 \\
25\end{array}$ \\
\hline $\begin{array}{l}\text { Daehwa } \\
\text { Industrial } \\
\text { Complex }\end{array}$ & $\begin{array}{l}\text { Platanus occidentalis } \\
\text { Ginkgo biloba }\end{array}$ & $\begin{array}{l}33 \\
16\end{array}$ & $\begin{array}{r}11 \\
7\end{array}$ & $\begin{array}{l}35 \\
20\end{array}$ \\
\hline
\end{tabular}

* D.B.H: Diameter of Breast Height.

most traffic and commercial areas are located in Daejeon station area. Many of commercial and chemical factory were in the Daehwa industrial complex. The new town and usually consists of residential and research areas was in Daedeok science town. The less traffic area was located in Chungnam National university site. The characteristics of the study species was in Table 1.

In study sites, soil samples under roadside trees, Ginko biloba and Platanus occidentalis, were collected from $0-10 \mathrm{~cm}$ soil depth by using an Oakfield soil sampler during September, 2004. Soils were air-dried and sieved to pass through a $2 \mathrm{~mm}$ sieve. All soil samples were analyzed by methods detailed by Bickelhaupt and White (1982). Soil samples were digested in a concentrated $\mathrm{HCl}$ and the heavy metal concentration was determined by ICP-AES. Tests of significance were set at the 0.05 level unless otherwise stated. The SAS computer software system was used in this study (SAS Institute, 1985).

The soil samples collected and transferred were stored in an ice pack at $4{ }^{\circ} \mathrm{C}$ in the laboratory. One milliliter of the appropriate $(10-5 \sim 10-7)$ dilutions of the soil samples was plated on nutrient agar's medium for the isolation of cultural microbes. Petri plates were then incubated, at $28^{\circ} \mathrm{C}$ for 48 hours for bacteria. After the required incubation period, DNA was extracted and purified using the QIAamp DNA stool Mini Kit (QIAgen Corp.) from colonies. The DNA of colonies emerged in the plates was identified by the molecular methods using SSU rDNA polymerase chain reaction (PCR)-based fingerprinting.

Our study focuses on the cultured bacterial community in general thus we are using primers 5'-GAGTTTGATCCTGGCTCAG-3' (9F: positions 9 to 27nt, E. coli 16S rDNA numbering) and 5'-ACGGCTACCTTGTTACGACTT-3'(1542R: positions 1542 to $1525 n t$, E. coli 16rDNA numbering). The PCR was performed using a MyGenie 32 Thermal Block (Bioneer Corp. Korea) and the following cycles: initial denaturation at $94^{\circ} \mathrm{C}$ for $5 \mathrm{~min}$ followed by 34 cycles of denaturation at $95^{\circ} \mathrm{C}$ for $1 \mathrm{~min}$, annealing at $60^{\circ} \mathrm{C}$ for $1 \mathrm{~min}$, and extension at $72^{\circ} \mathrm{C}$ for $1 \mathrm{~min} 30 \mathrm{~s}$, and final extension at $72^{\circ} \mathrm{C}$ for $7 \mathrm{~min}$. PCR products were examined on a $1 \%$ agarose gel and the DNA was diluted for sequencing and assessing.

Amplification of DNA with the eubacterium primer $9 \mathrm{~F}$ and 1542R produced almost the entire SSU gene fragments. PCR products were purified with QIAqick Gel extraction Kit (Qiagen, Corp.). DNA concentrations were quantified using a fluorometer. PCR products were sequenced by automatic sequencer ABIPRISMTM (Perkin-Elmer, USA at Eugenetech Co., Korea). After making the sequencing, GENDOC program, Tree View (3.2) and CLUSTAL X (v1.81; Thompson et al., 1994) were used for multiple alignment and neighbor-joining phylogeny (Saitou and Nei, 1987) using partial 16S rDNA gene sequences of species selected from gene bank of NCBI (http://www.nlm.nih.gov, Gehrig et al., 1996).

\section{RESULTS AND DISCUSSION}

The cadmium, copper, lead and zinc concentrations in soil of Ginko biloba ranged from 1.12 to $1.92,21.5$ to $28.2,17.2$ to 28.2 , and 50.0 to $429.5 \mathrm{mg} \mathrm{kg}^{-1}$ at $0-10 \mathrm{~cm}$ soil depth in the four study sites, respectively (Table 2). Li et al. (2001) reported that $\mathrm{Cd}, \mathrm{Cu}, \mathrm{Pb}$, and $\mathrm{Zn}$ concentration in urban soil of Hong Kong ranged from 0.02 to $5.89,5.12$ to $190,5.27$ to 404 , and 38.7 to $43.5 \mathrm{mg} \mathrm{kg}^{-1}$.

There was significant difference in the cadmium, copper, lead, and zinc concentrations among the four study sites of Ginko biloba. The percent cadmium, copper, lead, and zinc in soil was higher in heavy traffic area (Daejeon station) than in the light traffic area (Chungnam national university). The result could be from rubbing and wear of metal and car tire when they

Table 2. Soil cadmium, copper, lead, and zinc concentrations $\left(\mathrm{mg} \mathrm{kg}^{-1}\right)$ at $0 \sim 10 \mathrm{~cm}$ soil depth under roadside trees, Ginko biloba, in Daejeon metropolitan city.

\begin{tabular}{ccccr}
\hline Heavy metal & C.N.U* & D.S & D.I.C & D.S.T \\
\hline Cadmium & $1.29 \pm 0.10 \mathrm{~b}^{*}$ & $1.69 \pm 0.16 \mathrm{a}$ & $1.55 \pm 0.28 \mathrm{ab}$ & $1.65 \pm 0.27 \mathrm{ab}$ \\
Copper & $27.14 \pm 4.02 \mathrm{c}$ & $120.10 \pm 39.11 \mathrm{a}$ & $76.48 \pm 24.35 \mathrm{~b}$ & $40.40 \pm 6.04 \mathrm{bc}$ \\
Lead & $19.12 \pm 1.36 \mathrm{~b}$ & $25.50 \pm 2.65 \mathrm{a}$ & $24.62 \pm 2.65 \mathrm{a}$ & $24.96 \pm 2.86 \mathrm{a}$ \\
Zinc & $64.20 \pm 6.17 \mathrm{~b}$ & $276.80 \pm 120.1 \mathrm{a}$ & $109.14 \pm 26.83 \mathrm{~b}$ & $84.10 \pm 36.56 \mathrm{~b}$ \\
\hline
\end{tabular}

* C.N.U: Chungnam National University, D.S: Daejeon Station, D.I.C: Daehwa Industrial Complex, D.S.T: Daedeok Science Town.

* Different letters indicate statistical differences among the treatments at the $5 \%$ level. 
travel (Li et al., 2001; You and Son, 2003; Park, 1992).

The cadmium, copper, lead and zinc concentrations in soil of Platanus occidentalis ranged from 0.92 to $1.69,16.0$ to $288.0,16.9$ to 32.4 , and 100.0 to $415.0 \mathrm{mg}$ $\mathrm{kg}^{-1}$ in the four study sites, respectively (Table 3). There was significant difference in the copper and zinc concentrations among the four study sites. The percent copper and zinc in soil were higher in heavy traffic area (Daejeon station and Daewha industrial complex)than in the light traffic area (Chungnam national university). Li et al. (2001), You and Son (2003), and Park (1992) reported that high metal concentrations was found in heavy traffic areas in Hong Kong and Seoul, Korea. However, difference in the case of Ginko biloba, there was no significant difference in the cadmium and lead concentrations among the study sites because of probably soil variation.

Roadside soil samples were collected to examine microbe in the rhizosphere from study sites, Deajeon-station, Daehwa industrial complex, and Daedeok Science Town. We used nutrient agar medium to culture eubacterium after dilution (10-5 10-7). And then, the cell emerged in the plates cultured during 3 days used to identify species using SSU $16 \mathrm{~S}$ rDNA partial sequences. Colony number appeared in the plates was low level compared to general soil such as, agricultural and forest soils, Daejeon station appeared 15, Daehwa industrial complex 2, Daedeok science town 5. DNAs isolated from colony were subjected to PCR with bacterium-specific 16S rDNA primers (9F, 1542R). The size of the DNAs obtained with primers $9 \mathrm{~F}-1542 \mathrm{R}$ were consistent with those an amplified portion of the 16S rDNA.

Amplified DNAs were purified on agarose gel and sequenced automatic sequencer ABIPRISMTM (Perkin-Elmer, USA at Eugenetech Co., Korea). Two to 8 16S rDNA clones of 3 roadside tree soil samples were partially sequenced at the 5' end of the $16 \mathrm{~S}$ rDNA gene. From NCBI searching results, the sequences of DNA fragments obtained from colonies were synthesized to $1500 \mathrm{bps}$ and revealed to be similar to those of some eubacteria within comparison of $16 \mathrm{~S}$ rDNA sequences (Table 4).

Phylogenetic analyses revealed that roadside soil $16 \mathrm{~S}$ rDNA clones were classified as $\beta$-Proteobacteria, Actinobacteria, Gram-positive bacteria (George, 2001). DS-1, DIC- 1 , DS- 3 were $\beta$-Proteobacteria lineage, DS-3, DS-4, DS-5 were Actinobacteria and DS-6, DS-7, DIC-2 were Gram-positive bacteria lineage (Figure 1).

Similarity value was $96 \sim 99 \%$ except that DS-8 was $80 \%$. Roadside soil eubacteria of Daejeon station and Daedeok science town were general bacteria isolated from soils as streptomyces strains of Actinobacteria lineage, these organisms are strict aerobes (Tortora et al., 2002). Daehwa industrial complex represented only two colonies compare with other NA plates; these organisms are bacillus megaterium and agricultural soil bacterium. Daedeok science town's soil was identified as Streptomyces sp. The strains abundance varied between the three study sites. The Daejeon station area showed the highest microbial colony, followed by the Daedeok science town and Daehwa industrial complex

Table 3. Soil cadmium, copper, lead, and zinc concentrations $\left(\mathrm{mg} \mathrm{kg}^{-1}\right)$ at $0 \sim 10 \mathrm{~cm}$ soil depth under roadside trees, Platanus occidentalis, in Daejeon metropolitan city.

\begin{tabular}{ccccc}
\hline Soil depth $(\mathrm{cm})$ & C.N.U* & D.S & D.I.C & D.S.T \\
\hline Cadmium & $1.14 \pm 0.27 \mathrm{a}^{*}$ & $1.18 \pm 0.15 \mathrm{a}$ & $1.43 \pm 0.18 \mathrm{a}$ & $1.32 \pm 0.18 \mathrm{a}$ \\
Copper & $22.40 \pm 5.49 \mathrm{~b}^{*}$ & $116.20 \pm 93.37 \mathrm{a}$ & $48.10 \pm 10.92 \mathrm{ab}$ & $27.10 \pm 5.79 \mathrm{~b}$ \\
Lead & $22.02 \pm 4.55 \mathrm{a}^{*}$ & $24.36 \pm 4.35 \mathrm{a}$ & $25.98 \pm 4.29 \mathrm{a}$ & $21.98 \pm 1.14 \mathrm{a}$ \\
Zinc & $103.20 \pm 4.31 \mathrm{~b}^{*}$ & $231.20 \pm 114.71 \mathrm{a}$ & $154.30 \pm 14.13 \mathrm{ab}$ & $124.20 \pm 12.01 \mathrm{~b}$ \\
\hline
\end{tabular}

* C.N.U: Chungnam National University, D.S: Daejeon Station, D.I.C: Daehwa Industrial Complex, D.S.T: Daedeok Science Town.

* Different letters indicate statistical differences among the treatments at the $5 \%$ level.

Table 4. Identification of the $16 \mathrm{~S}$ rDNA sequencing from roadside tree soil samples.

\begin{tabular}{cccc}
\hline No. & 16S rDNA identification & Accession number & Sequence similarity (\%) \\
\hline DS-1 & Agricultural soil bacterium & AJ252575 & $697 / 703(99 \%)$ \\
DS-2 & Streptomyces lincolnensis & X79854 & $770 / 797(96 \%)$ \\
DS-3 & Agricultural soil bacterium & AJ252575 & $680 / 693(98 \%)$ \\
DS-4 & Streptomyces capoamus & AB045877 & $775 / 793(97 \%)$ \\
DS-5 & Rhodococcus wratislaviensis & AY785739 & $681 / 757(89 \%)$ \\
DS-6 & Bacillus benzoevorans & AY167808 & $714 / 718(99 \%)$ \\
DS-7 & Uncultured Bacillus sp. & AY876909 & $362 / 389(93 \%)$ \\
DS-8 & Streptomyces sp. & AF131520 & $545 / 675(80 \%)$ \\
DIC-1 & Agricultural soil bacterium & AJ252575 & $701 / 703(99 \%)$ \\
DIC-2 & Bacillus megaterium & AY030338 & $751 / 768(97 \%)$ \\
DS-1 & Streptomyces sp. & AF131563 & $809 / 830(97 \%)$ \\
\hline
\end{tabular}

* DS: Daejeon station, DIC: Daehwa industrial complex, DS: Daedeok science town. 


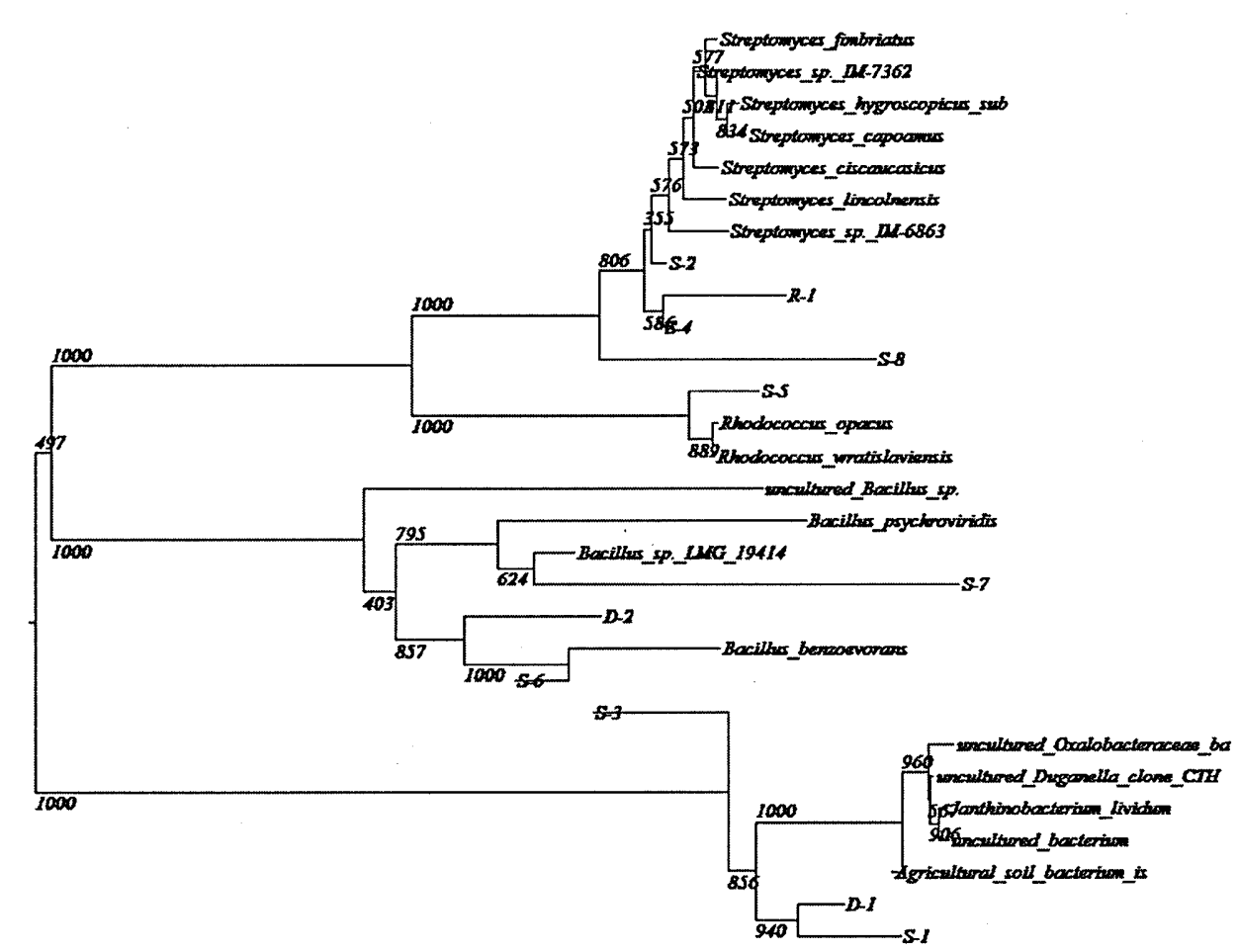

Fig. 1. Phylogenetic tree showing the affiliations of $16 \mathrm{~S}$ rDNA clone sequences of roadside tree soil eubacteria.

was the lowest. This study could not find relation between strains richness and heavy metal. But we could see more simple bacteria condition in the industrial complex than other areas. Forward, to know roadside tree soil's ecological condition near the polluted source such as automobile exhaust fume and smoke pollution, it is need to monitor continuously to know the soil condition

\section{REFERENCES}

Amann, R. I., W. Ludwig and K. H. Schleifer 1995 Phylogenetic identification and in situ detection of individual microbial cells without cultivation. Microbiol Rev. 59: 143-169

Bianciotoo, V., S. Andreotti, R. Balestrini, P. Bonfante and S. Perotto 2001 Mucoid mutants of the biocontro strain Pseudomonus fluorescens CHA0 show increased ability in biofilm formation on mycorrhizal and nonmycorrhizal carrot roots. Mol. Plant-Microbe Interact. 14: 255-260

Bickelhaupt, D. H. and E. H. White 1982 Laboratory Manual for Soil and Plant Tissue Analysis. SUNY Coll. Envir. Sci. and For., Syracuse, N.Y. pp. 67

Garcia, R. and E. Millan 1994 Heavy metal contents from road soil in Guipuzcoa (Spain). The science of the Total Environment. 14: 147, 157-161

Gibson, M. G. and J. G. Farmer 1986 Multi-step chemical extraction of heavy metals from urban soils. Environ. Pollut.

\section{B 11: $117-135$}

George, M. G. 2001 Bergey's Mannual of Systematic Bacteriology, Springer-Verlag, New York

Harrison, R. M., D. P. H. Laxen and S. J. Wilson 1981 Chemical association of lead, cadmium, copper, and zinc in street dust and roadside soil. Environ. Sci. Technol. 15: 1378-1383

Howells, J. 1991 In Lead Minerals in Soils Contaminated by Mine-waste: Implications for Human Health. Univ. of London, pp. 250

Li, X., C. S. Poon and P. S. Liu 2001 Heavy metal contamination of urban soils and street dusts in Hong Kong. Appl. Geochem., 16: 1361-1368

Park, G. H. $1992 \mathrm{~Pb}, \mathrm{Cu}, \mathrm{Zn}$ contaminants and their correlation of soil, leave and bark of Ginko B. and ambient air adjacent to a heavy traffic road side. Kor. J. Envir. Hlth. Soc., 18: 19-25

Saitou, N. and M. Nei 1987 The neighbor-joining method: a new method for reconstructing phylogenetic tree. Mol. Biol. Evol. 4: $406-425$

SAS. 1998 SAS/STAT User's Guide, 6.03 edition. SAS Institute, Cray, NC, USA.

Thornton, I. 1991 Metal contamination of soils in urban areas. In "Soils in the Urban Environment", ed. by P. Bullock and P. J. Gregory Blackwell, pp. 47-75

Thomson, J. D., D. G. Higgins and T. J. Gibson 1994 CLUSTAL $\mathrm{W}$ : improving the sensibility of multiple sequence alignment through sequence weighting, position specific gap penalties and weight matrix choice. Nucleic Acid Res. 26:179-182

Tortora, G. J., B. R. Funke and C. L. Case 2002 Microbiology an Introduction. Benjamin Cummings Publishers (USA) 